\title{
Photovoltaic Integrated Distributed Energy Generation System for Sustainable Energy Development Considering Reliability Indices and Levelized Cost of Energy
}

\author{
Muhammad Tamoor ${ }^{1 *}$, Muhammad Abu Bakar Tahir ${ }^{2}$, Muhammad Ans Zaka ${ }^{3}$ \\ ${ }^{1}$ PhD Scholar, Department of Electrical Engineering and Technology, GC University Faisalabad, Pakistan \\ ${ }^{2}$ MS Scholar, Automotive Engineering for Sustainable Mobility, University of Orleans, France \\ ${ }^{3}$ Energy and Environmental Engineer, Zeecon Engineering Services Pakistan \\ *Corresponding Author Email Address: phd.20.muhammadtamoor@gmail.com
}

\section{ABSTRACT}

This research presents the photovoltaic integrated distributed energy generation system for sustainable energy development considering reliability indices and levelized cost of energy (LCOE). The reliability indices calculate based on failure rates, repair times and annual outage times in Electrical Transient and Analysis Program (ETAP) software. Expected interruption cost (ECOST) in reliability indices is evaluated with the analytical method. It is used based on the customer damage function (CDF) according to the survey in the test area. In this research, the calculation of the levelized cost of energy (LCOE) describes from 2018 to 2025 . The case study of this paper is carried out on one of the distribution system which consists of $11 \mathrm{kV}$ Samundri feeder line feed from 132 $\mathrm{kV}$ distribution grid station located in Faisalabad, Pakistan. The design and annual energy production of integrated photovoltaic system is evaluated by using HelioScope simulation tool. According to reliability assessment of test system before integrating PV DG, average service availability index (ASAI) is 0.9642 pu and average service unavailability index (ASUI) is 0.03585 . Then, expected energy not supplied (EENS) is $643.359 \mathrm{MWh} /$ year. After integrating PV DG, average service availability index (ASAI) is $0.9735 \mathrm{pu}$ and average service unavailability index (ASUI) is 0.02645 . Then, expected energy not supplied (EENS) is 469.882 MWh/year. Based on EENS, after integrating the PV DG the system reliability is increased by 27.0 percent. Similarly before PV DG integration, expected interruption cost (ECOST) is 322,210,390.15 PKR/year and after integration expected interruption cost (ECOST) is 189,239,286.16 PKR/year.
Key words: Distributed generation, Photovoltaic system, Integration of renewable energy source, Reliability indices, Interruption cost, Levelized cost of energy

\section{INTRODUCTION}

The international energy agency (IEA) predicts that by 2040, global energy demand will increase by more than 25.0 percent [1]. As a result, developing countries are move toward to integrated resources planning to promote renewable energy generation. According to this data, it is expected that the demand and installation of distributed grid-connected (DG) power generation system are rapidly increasing [2-5]. Because of its flexibility and ability to provide renewable energy, microgrids can be considered as a feasible solution for distributed power generation system connected to national electrical grid. So far, more than 300.0 micro-grid (MG) projects have been established around the world, with a total capacity of more than 1.50 gigawatt [6]. Distributed power generation system is defined as "an energy source directly connected to the electrical distribution system/network" [7].

The electrical distribution system can sustain increasing load demands by incorporating distributed power sources. To meet rising demands of load, a detailed comparison and assessment of distributed energy sources, such as PV energy are performed $[8,9]$. Electrical loads and distributed generation (DG) (like PV) are combined with an electrical storage system in the power distribution system [10]. Several detailed research on sustainable energy generation and management are available in this area. The development of renewable energy systems, including photovoltaic energy, wind energy, biomass energy, geothermal energy, small hydroelectric energy, tidal energy, and state policies are analyzed for 
different countries [11-13]. Energy management systems was designed and implemented for integration of renewable energy sources in to microgrid. Energy management systems could assure the safe functioning of island microgrids (MGs), when there is imbalance between power generation and load demand [14]. With the deepening of the energy crisis, the power distribution system integrated with different renewable energy resources is a best solution and can be used as a supplement to the central grid system of the country [15].

Sustainable energy system require renewable and the dispatchables energy resources. Photovoltaic energy is a rich source of renewable energy in the world [16]. Pakistan is a developing countries and annually receives nearly $15.525 \times$ $10^{14}$ kilowatt-hour of solar energy, and the sunshine period is generally $7.50-10.50$ hours/day [17]. Photovoltaic distributed power generation systems can make a positive contribution to the sustainability of developing countries. The integration of photovoltaic distributed power generation systems with central grid network will help to meet the growing demand of electricity. More use of photovoltaic distributed generation systems can also improve the reliability of the power grid [18].

To meet local demand, distributed energy sources such as controllable loads and distributed generators are managed in the form of multiple microgrids in the active distribution network. On the other hand, the load of some distribution network may be provided by the retailer participating in the energy wholesale market. A bi-level optimization methodology to model the interaction between retailers and microgrids in distribution networks is proposed to increase the retailer profit and reduce the cost of microgrid [19]. In a distribution system, a distributed method for reactive power management has been presented to focuse on the voltage (V) rise of a power distribution system equipped with a large number of PV systems [20].

In this research, PV DG (distributed generation) is used as a reliable power system and sustainable source that can provide customer loads without interrupting the power supply. In comparison with other type renewable energy resources, PV DG (distributed generation) is more convenient because the test area is situated in tropical zone.

Moreover, the cost of a reliable power system must be considered. One possible way to consider customer benefits is to use the cost of energy not supplied (undelivered energy) (money/kWh) or/and the cost per interrupted power (money $/ \mathrm{kW}$ ) as an adjustable measure of the severity of the interruption [21].

The basic concepts related to power system reliability cost/worth evaluation are shown in figure 1 . There is a minimum point in the resulting total cost curve that indicate the optimal target level of the reliability. The reliability cost/ worth analysis are performed to find-out the optimal point.

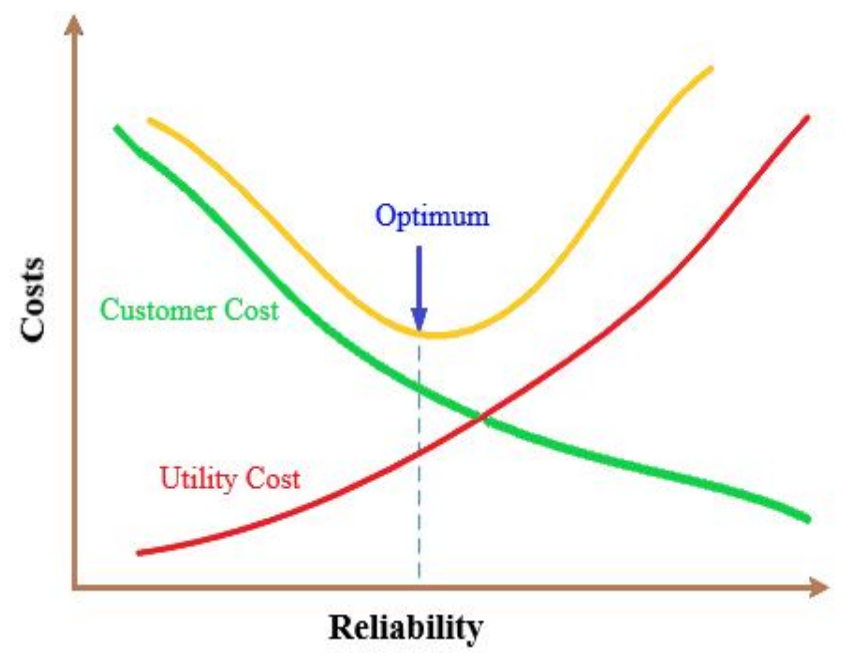

Figure 1: Power system reliability cost/worth

In Pakistan, power distribution system is not fully operational and many interruption or power outages occurs due to faults of old components in distribution networks and sometime failure due to weather (e.g. thunderstorm). The $500 / 132 \mathrm{kV}$ transmission grid station (NTDC) located in the Gujranwala District in Pakistan is feed by $500 \mathrm{kV}$ double circuit transmission lines from Mangla and Terbela Hydro-power generating stations. This transmission grid station feed the 132/11 kV distribution grid station located in Faisalabad District in Pakistan. In this research, the test system is radial distribution network and the single line diagram of $132 / 11 \mathrm{kV}$ distribution grid station and Samundri road feeder are shown in Figure 2.

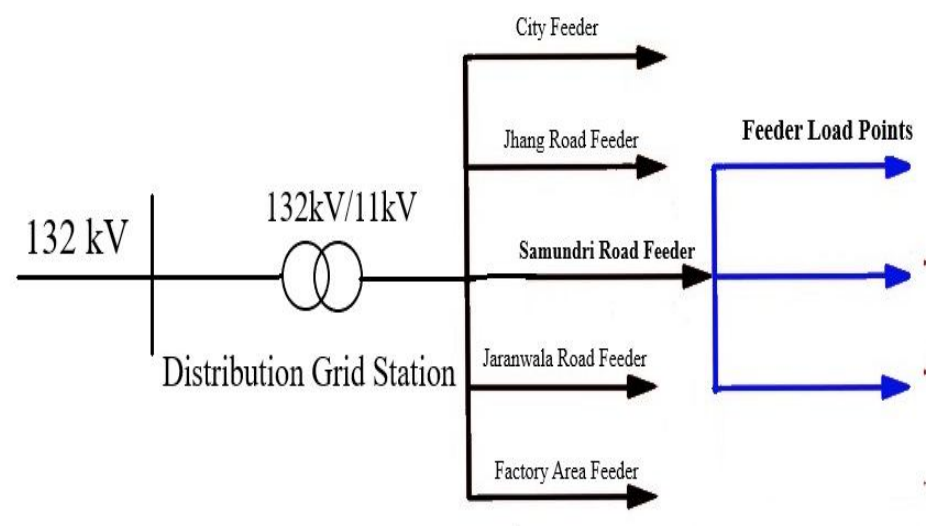

Figure 2: Single line diagram of Samundri road feeder line 
Distribution system of this research based on analytical evaluations that includes the evaluation of suitable adequacy indices at the actual consumer load point. The basic load point indices are the load point failure rates $(\lambda)$, average outage times (r) and average annual unavailability or outage (U). These three basic reliability parameters are calculated by the equations given below [22].

$\lambda_{s}=\sum_{i=1}^{N} \lambda_{i}$ interruption/year

$\mathrm{U}_{s}=\sum_{i=1}^{N t} \lambda_{i} r_{i}$ hour $/$ year

(2)

$\mathbf{r}_{s}=\frac{U_{s}}{\lambda_{s}}$ hour $/$ year

(3)

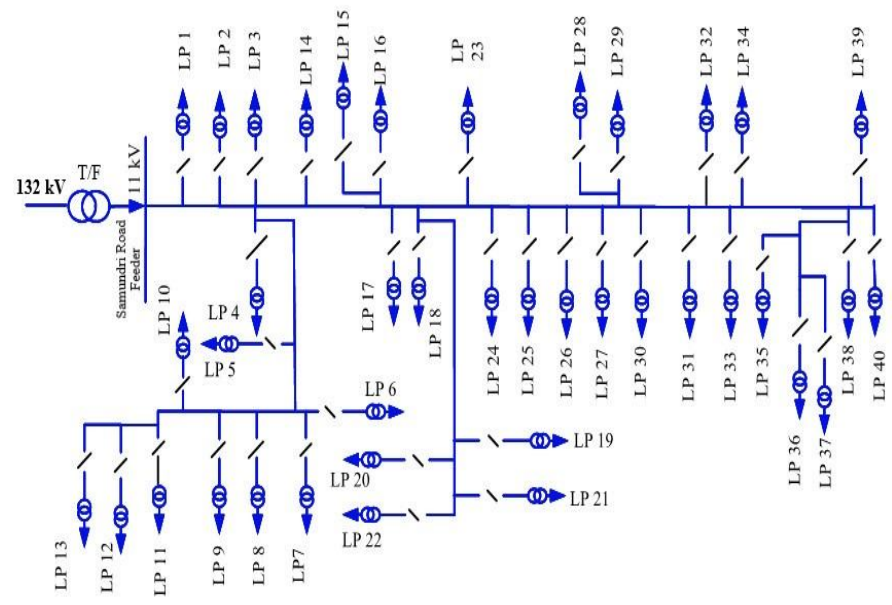

Figure 3: Samundri road feeder line distribution network

Figure 3 shows the Samundri road feeder line distribution network. There are 40.0 load points and its length has 10.0 miles and its lateral points have 0.60 miles. Its total load is 3.0 MW, total customer of Samundri road feeder is 3602.0. The power outage data of test system such as earthing/grounding fault, over current fault and power unavailability were collected from the $132 / 11 \mathrm{kV}$ distribution grid station, Faisalabad [23].

\section{METHODOLOGY}

In this research, reliability assessment of the test system is simulated by the Electrical Transient and Analysis Program (ETAP) software and expected interruption cost (ECOST) was evaluated by using analytical method. HelioScope simulation tool is used for designing and estimation of annual power production of integrated PV test system.

\subsection{Reliability Assessment in ETAP Software}

The basic indices are very important but they do not provide the complete response and behavior of the system. Therefore, in this research, the following reliability indices such as system average interruption frequency index (SAFI), system average interruption duration index (SAIDI), customer average interruption duration index (CAIDI), average service availability index (ASAI), average service unavailability index (ASUI), expected energy not supplied index (EENS) and average energy not supplied index (AENS) are calculated to get the complete assessment of distribution system. The equations of above mentioned reliability indices are given below [22].

SAIFI $=\frac{\text { Total No. of the Customer Interruptions }}{\text { Total No. of the Customer Served }}$

$=\frac{\sum \lambda_{\mathrm{i}} N_{i}}{\sum N_{\mathrm{i}}}$ failure/customer/year

SAIDI $=\frac{\text { Sum of the Customer Interruptions Duration }}{\text { Total No.of the Customer Served }}$

$=\frac{\sum \mathrm{U}_{\mathrm{i}} N_{i}}{\sum \mathrm{N}_{\mathrm{i}}}$ hour $/$ customer $/$ year

CAIDI $=\frac{\text { Sum of the Customer Interruptions Duration }}{\text { Total No. of the Customer Interruptions }}$

$=\frac{\sum U_{i} N_{i}}{\sum \lambda_{i} N_{1}}$ hour/customer interruption/
year

(6)

(8)

ASUI $=1-$ ASAI 
EENS $_{i}=\mathrm{Pi}:$ Ui $\mathrm{MWh} /$ year

$\mathrm{EENS}=\sum_{\mathrm{i}}^{\mathrm{N}} \mathrm{EENS}_{1} \mathrm{MWh} /$ year

AENS $=\frac{\text { Total Energy Not Supllied by System }}{\text { Total Number of Customer Served }}$

$=\frac{\sum \text { EENS }_{\mathrm{i}}}{\sum N_{\mathrm{i}}}$

Where

- $\mathrm{N}_{\mathrm{i}}$ : number of customer served at load point $\mathrm{i}$

- $\lambda_{\mathrm{i}}$ : failure rate $(\lambda)$ at load point $\mathrm{i}$

- $\mathrm{U}_{\mathrm{i}}$ : outage time at load point $\mathrm{i}$

- $\mathrm{P}_{\mathrm{i}}$ : average load demand at load point $\mathrm{i}$

\subsection{Expected Interruption Cost in Analytical Method}

The analytical method to assess the expected interruption cost (ECOST) and the interrupted energy assessment rate (IEAR) indices are evaluated in the following equations [24].

$$
\begin{aligned}
\lambda_{i j}=\lambda \prod_{j} \prod_{k=1}^{N} 1-P_{k} \\
\quad r_{i j}=P_{a} S_{j}+\left(1-P_{a}\right) r_{j}
\end{aligned}
$$

$\mathrm{C}_{\mathrm{ij}}=f\left(\mathrm{r}_{\mathrm{ij}}\right)$

$\operatorname{ECOST}_{i}=\sum_{j=1}^{N_{e}} c_{i j} L_{i} \lambda_{i j}=L_{i} \sum_{j=1}^{N_{e}} c_{i j} \lambda_{i j}$

$I E A R_{i}=\frac{E C O S T_{i}}{E E N S_{i}}$

$E \operatorname{COST} T_{i}=\sum_{i=1}^{N_{p}} E \operatorname{COST} T_{i}$

$I E A R=\frac{E C O S T}{E E N S}$

Where, $P_{a}$ is the probability that restore supply, $P_{k}$ is the probability of the fuse or breaker " $\mathrm{k}$ " operates, $\mathrm{N}_{\mathrm{e}}$ is per unit $(\mathrm{kW})$ interruption cost $c_{\mathrm{ij}}$ using SCDF, ECOST $\mathrm{T}_{\mathrm{i}}$ is expected interruption cost in load point $\mathrm{i}, \mathrm{IEAR}_{\mathrm{i}}$ is interrupted energy assessment rate at load point $I$ and $L_{i}$ is average load at load point $i$. The flow chart of interruption cost evaluation in analytical method shows in Figure 4.

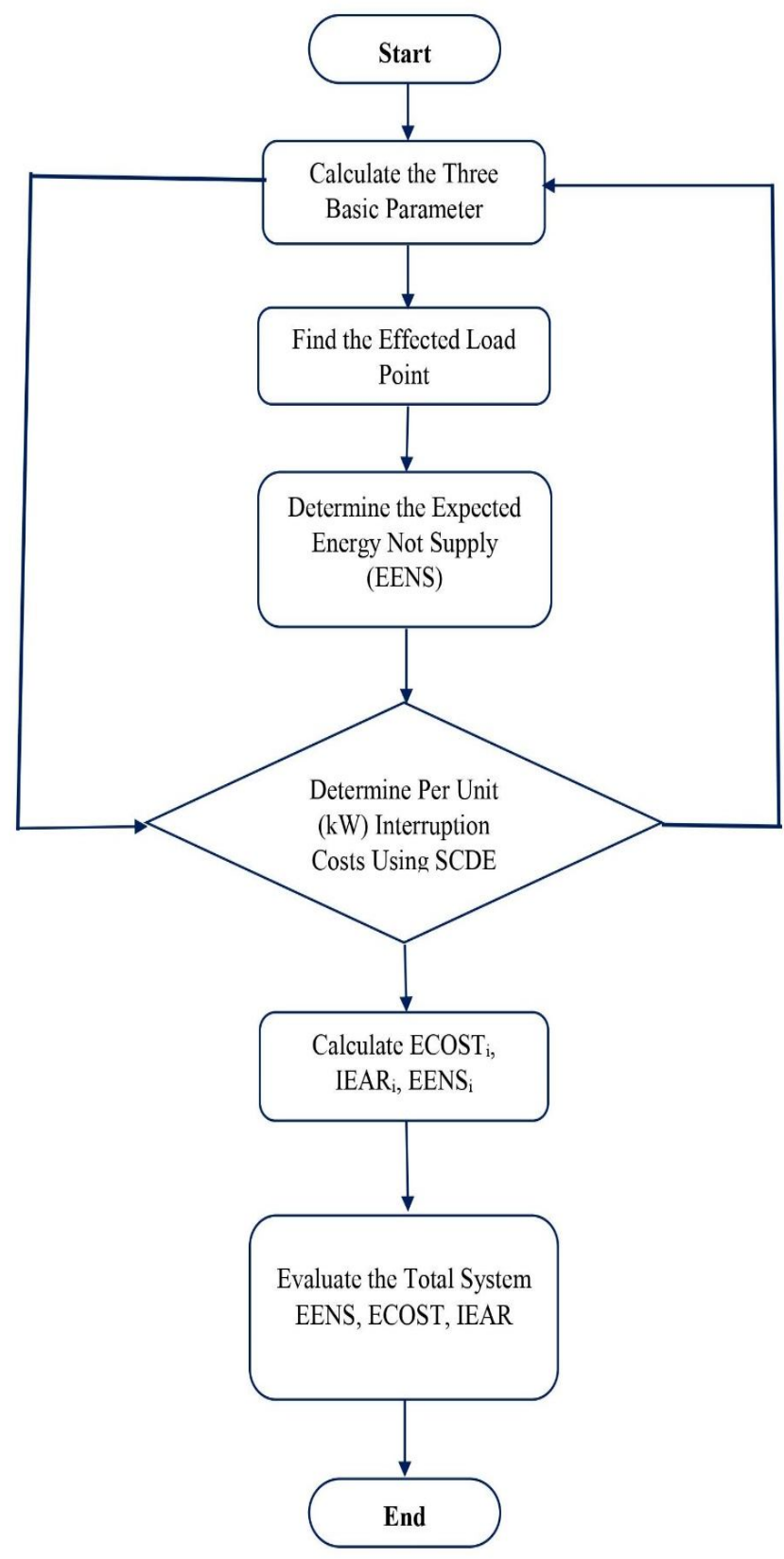

Figure 4: Flow chart of interruption cost in analytical method

\section{RESULTS}

\subsection{Reliability Analysis of Test System}

Test system in this research is the $11 \mathrm{kV}$ Samundri road feeder line of 132/11 kV distribution grid station, Faisalabad. In this section, the basic case reliability assessment describes and then shows the PV integrated distributed generation in the test area. 


\subsubsection{Base Case Reliability Analysis Before DG Integrating}

The methods of the reliability assessment of the power distribution system are analytical method. This method is solution of the mathematical model and the simulation method is based on statistical distributions data in ETAP software. Table 1 shows the customer types and load of the test system. According to the data collection of test area, there are three types of customers i.e. commercial, industrial and residential. Table 2 shows the interruption cost data in $\mathrm{PKR} / \mathrm{kW}$ of peak demand for the three types of customer according to the survey costs of customers per hour in the test area.

Table 1: Customer types and load of the test system

\begin{tabular}{|l|c|c|c|}
\hline $\begin{array}{c}\text { Customer } \\
\text { Type }\end{array}$ & $\begin{array}{c}\text { No. of } \\
\text { Customer }\end{array}$ & Load Point & $\begin{array}{c}\text { Average } \\
\text { Load per } \\
\text { Load } \\
\text { Point(kW) }\end{array}$ \\
\hline Industrial & 1 & 32 & 22.1 \\
\hline Residential & 318 & $\begin{array}{c}14,18,33,34,36, \\
38\end{array}$ & 22.1 \\
\hline $\begin{array}{l}\text { Commercia } \\
1\end{array}$ & 6 & $3,9,12,13,17,24$ & 22.1 \\
\hline Residential & 830 & $11,20,25,26,29$, & 32.3 \\
\hline $\begin{array}{l}\text { Commercia } \\
1\end{array}$ & 2 & $37,39,40$ & 32.3 \\
\hline Residential & 567 & $10,22,27,35$ & 41.65 \\
\hline $\begin{array}{l}\text { Commercia } \\
1\end{array}$ & 2 & 7,8 & 41.65 \\
\hline Residential & 735 & $19,21,28,31$, & 51.85 \\
\hline Industrial & 1 & 1 & 62.05 \\
\hline Industrial & 1 & 6 & 72.25 \\
\hline $\begin{array}{l}\text { Commercia } \\
1\end{array}$ & 1 & 5 & 121 \\
\hline Industrial & 220 & 2 & 132 \\
\hline Residential & 366 & 16 & 142 \\
\hline Residential & 369 & 4 & 192 \\
\hline Residential & 183 & 23 & 262 \\
\hline $\begin{array}{l}\text { Total No. } \\
\text { of }\end{array}$ & & 3602 & \\
\hline Customer & & & \\
\hline
\end{tabular}

Table 2: Customer Interruption Costs (PKR/kW)

\begin{tabular}{|c|c|c|c|}
\hline & \multicolumn{3}{|c|}{ Types of Customer } \\
\hline $\begin{array}{c}\text { Duration } \\
(\mathbf{m i n})\end{array}$ & $\begin{array}{c}\text { Commercial } \\
\text { PKR/kW }\end{array}$ & $\begin{array}{c}\text { Industrial } \\
\mathbf{P K R / k W}\end{array}$ & $\begin{array}{c}\text { Residential } \\
\text { PKR/kW }\end{array}$ \\
\hline 1 & - & - & - \\
\hline 20 & 3000 & 500 & - \\
\hline 60 & 10000 & 2000 & 500 \\
\hline 240 & 40000 & 8000 & 2000 \\
\hline
\end{tabular}

Figure 5 shows reliability assessment of test system before integrating PV DG by using the ETAP Software. The ETAP software calculate several reliability indices of each load point of test system. The failure rates of test system (for example high consuming load, far away from the supply feeder and many tap points in one lateral) are more interrupt than others failures.

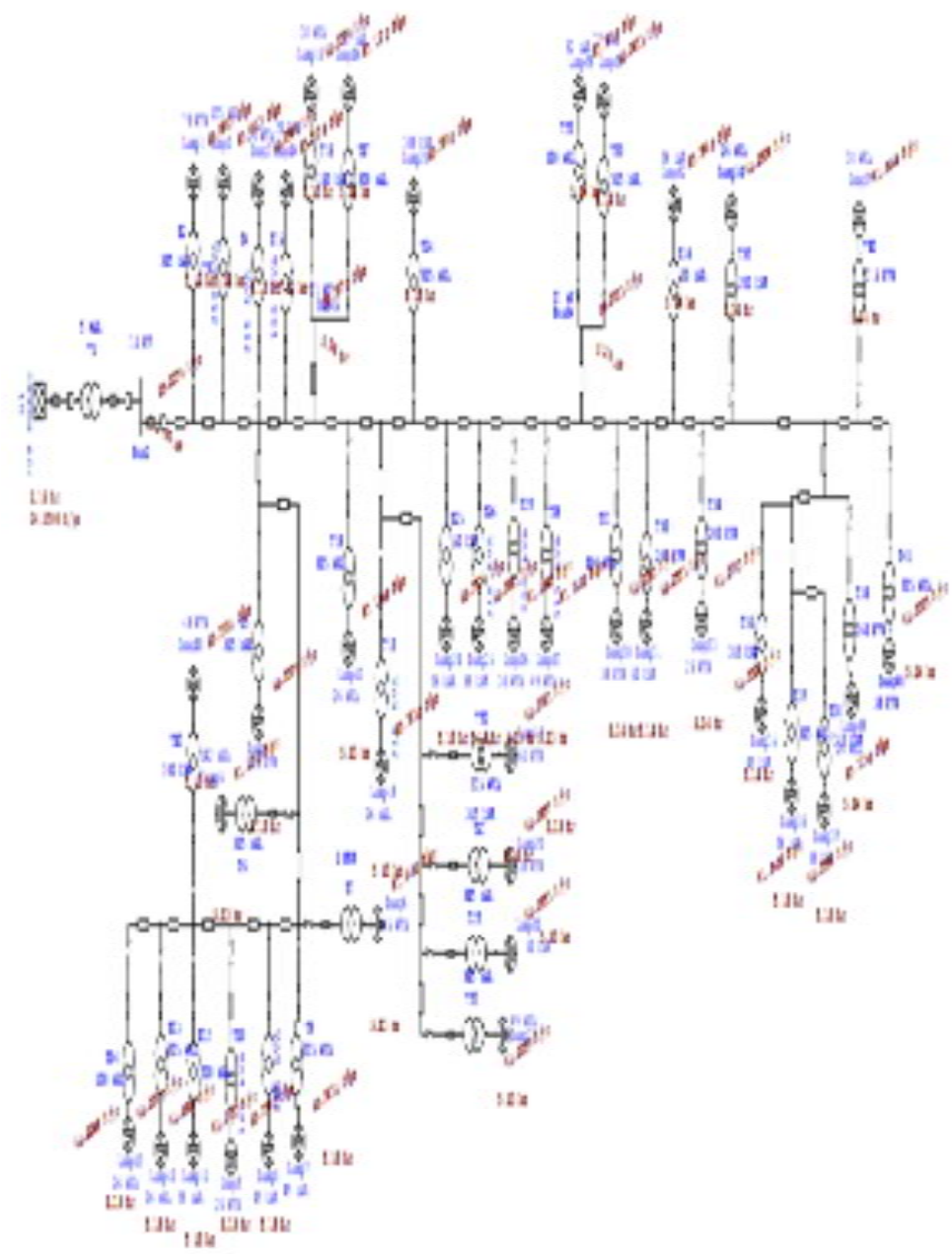

Figure 5: Reliability assessment of test system before integrating PV DG by using ETAP Software

According to reliability assessment of test system before integrating PV DG, the average service availability index (ASAI) is $0.9642 \mathrm{pu}$ and the average service unavailability index (ASUI) is 0.03585 . Therefore, expected energy not supplied (EENS) is $643.359 \mathrm{MWh} /$ year and average energy 
not supplied (AENS) is $0.1859 \mathrm{MWh} /$ customer/year. Expected interruption cost (ECOST) is 322,210,390.15 $\mathrm{PKR} / y e a r$ and interrupted energy assessment rate (IEAR) is 565.0 PKR/year. These results are shown in Table 4.

\subsubsection{Reliability Analysis of Integrated PV Distributed Generation in Test System}

Grid-tied distributed generation (DG) systems such as solar photovoltaic (PV) systems, wind energy, diesel generator, biomass combined heat and power (CHP), etc. are appropriate technologies for residential, commercial and industrial application. This research considers the PV DG (distributed generation) as additional power source to improves the test system reliability. The PV DG (distributed generation) is more suitable because the test area is situated in tropical zone. So, this paper considers the $500.04 \mathrm{~kW}$ PV DG type to improve the system reliability. The parameters of solar module panel are: Model JA Solar (JAM72S30-540/MR), maximum power: $540 \mathrm{~W}$, open-circuit voltage: $49.600 \mathrm{~V}$, short-circuit current: $13.860 \mathrm{~A}$, Current at maximum power: 12.970A, Voltage at maximum power: $41.640 \mathrm{~V}$, cell efficiency $16.1 \%$, module efficiency $15.1 \%$, Temp Coefficient $\mathrm{P}_{\max }:-0.350 \% /{ }^{\circ} \mathrm{C}$ and life expectancy: 25 years.

From HelioScope simulation result we found that the integrated photovoltaic system annual production of is 754.9 MWh and integrated photovoltaic system performance ratio is $82.40 \%$. Table 3 Integrated photovoltaic system Monthly Energy to Grid and Nameplate ( $\mathrm{kWh}$ ) comparison. Figure 6 shows the Monthly Energy to Grid (kWh) for each month of year.

Table 3: Integrated photovoltaic system Monthly Energy to Grid and Nameplate $(\mathrm{kWh})$ comparison

\begin{tabular}{|l|c|c|c|}
\hline \multicolumn{1}{|c|}{ Month } & $\begin{array}{c}\mathbf{G H I} \\
\left(\mathbf{k W h} / \mathbf{m}^{2}\right)\end{array}$ & $\begin{array}{c}\text { Nameplate } \\
(\mathbf{k W h})\end{array}$ & $\begin{array}{c}\text { Monthly } \\
\text { Energy to } \\
\text { Grid }(\mathbf{k W h})\end{array}$ \\
\hline January & 88.5 & $50,746.5$ & $46,842.8$ \\
\hline February & 106.6 & $59,200.9$ & $53,766.4$ \\
\hline March & 147.6 & $76,925.9$ & $68,082.6$ \\
\hline April & 165.8 & $81,461.7$ & $70,799.9$ \\
\hline May & 186.5 & $87,839.6$ & $74,992.6$ \\
\hline June & 187.1 & $86,426.7$ & $73,789.9$ \\
\hline July & 169.7 & $78,841.4$ & $68,057.9$ \\
\hline August & 168.9 & $81,162.9$ & $69,961.1$ \\
\hline September & 156.0 & $79,447.3$ & $68,733.4$ \\
\hline October & 130.7 & $70,458.8$ & $61,611.6$ \\
\hline November & 100.3 & $57,619.7$ & $51,814.8$ \\
\hline December & 86.2 & $50,866.5$ & $46,414.9$ \\
\hline \multicolumn{3}{|c|}{ Energy to Grid (kWh) } & $754,867.8$ \\
\hline
\end{tabular}

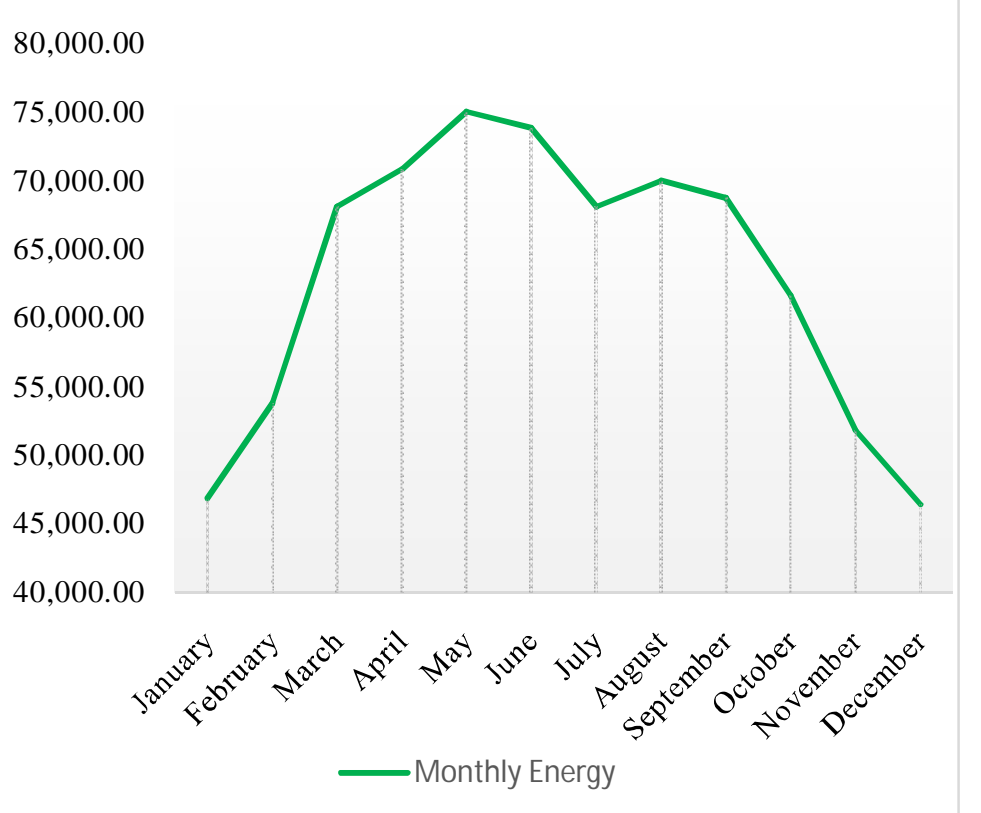

Figure 6: Monthly Energy to Grid (kWh) for each month of year
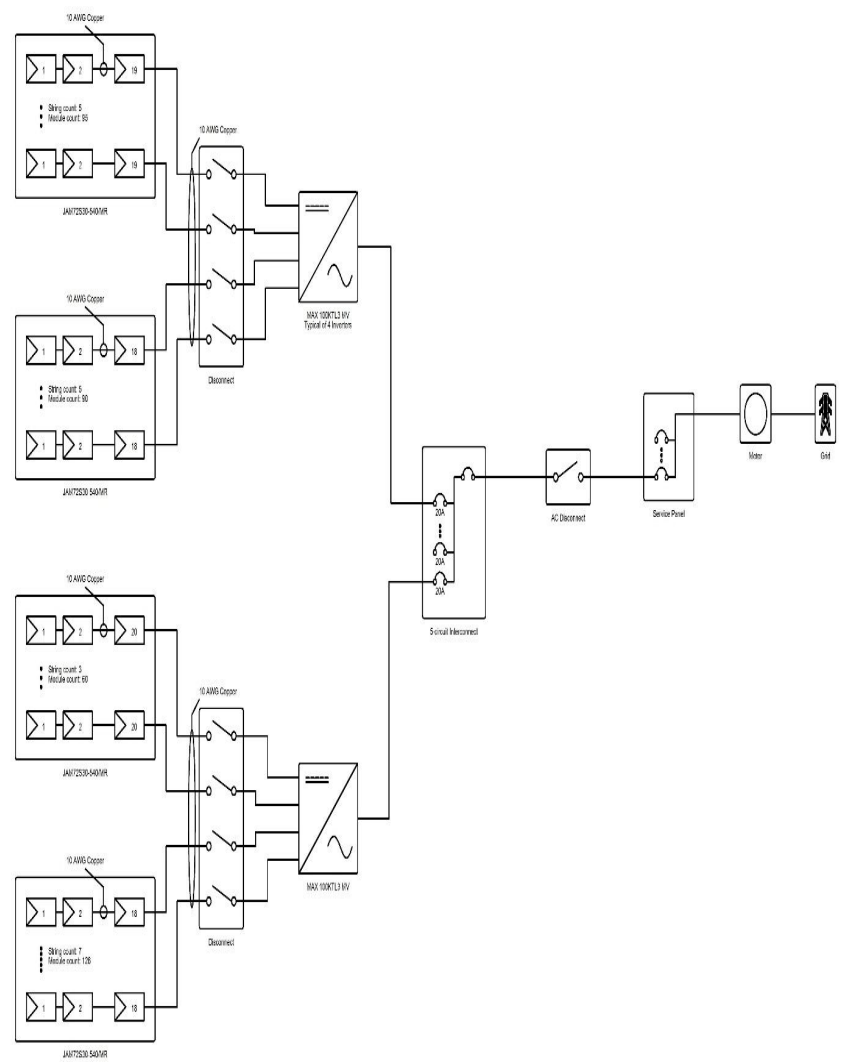

Figure 7: Single line diagram of integrated photovoltaic system

After integrated photovoltaic system simulation, we find reliability analysis of integrated PV distributed generation in test system. According to reliability assessment of test system after integrating PV DG, average service availability index (ASAI) is $0.9735 \mathrm{pu}$ and average service unavailability index 
(ASUI) is 0.02645 . Then, expected energy not supplied (EENS) is $469.882 \mathrm{MWh} /$ year and average energy not supplied (AENS) is $0.1358 \mathrm{MWh} /$ customer/year. Expected interruption cost (ECOST) is 189,239,286.16 PKR/year and interrupted energy assessment rate (IEAR) is 464.0 PKR/year.

The comparison of the expected energy not supply with two conditions are shown in Figure 8. The comparison of ECOST of each load point in two conditions (with DG and without DG) are shown in Figure 9 and then comparison of interruption cost for two condition is shown in Figure 10. Reliability assessment results of two conditions (with and without DG) presents the Table 4. According to the interruption costs in analytical method, the difference of interruption energy assessment rate between PV DG integrating condition and normal case condition can be seen in Table 4.

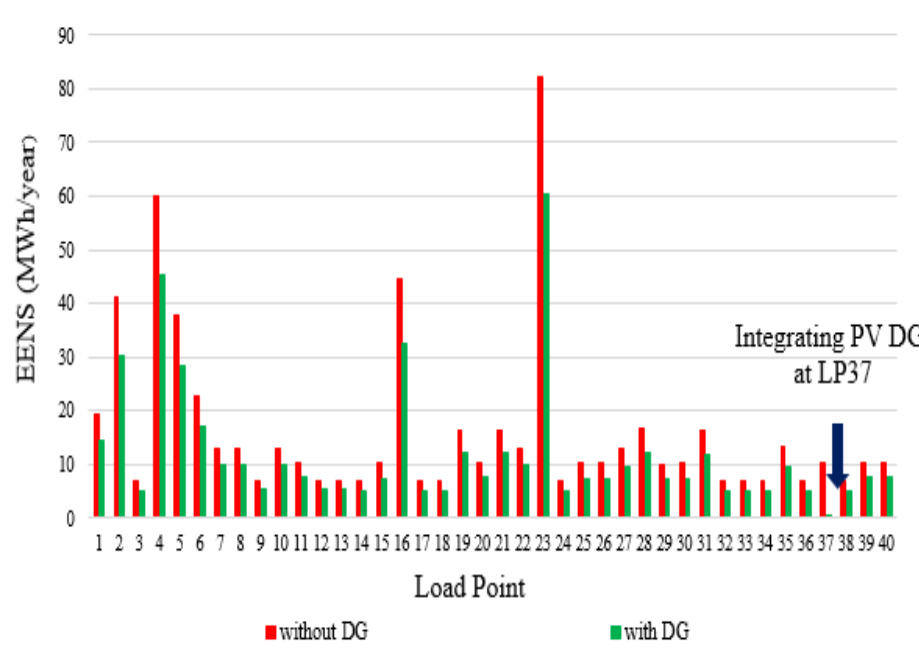

Figure 8: Comparison of EENS of each load point in two condition (with and without DG)

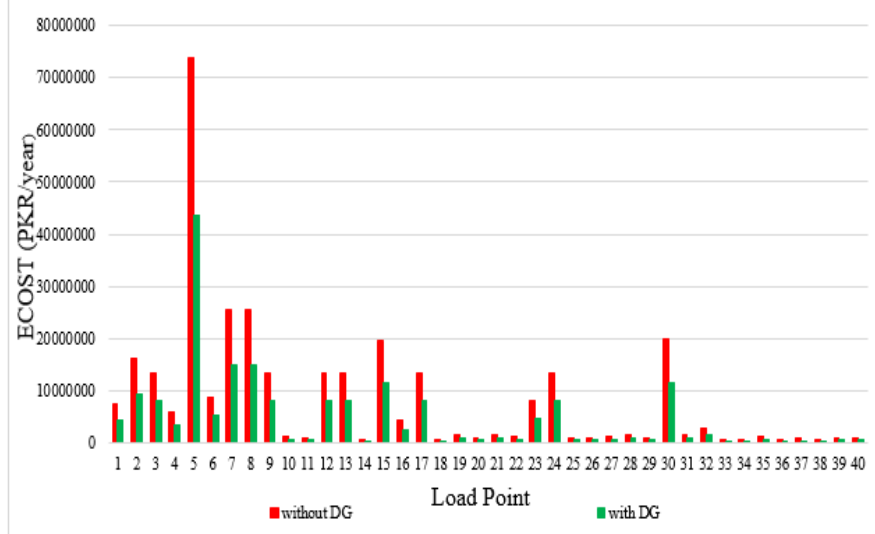

Figure 9: Comparison of interruption costs of each load point in two condition (with and without DG)

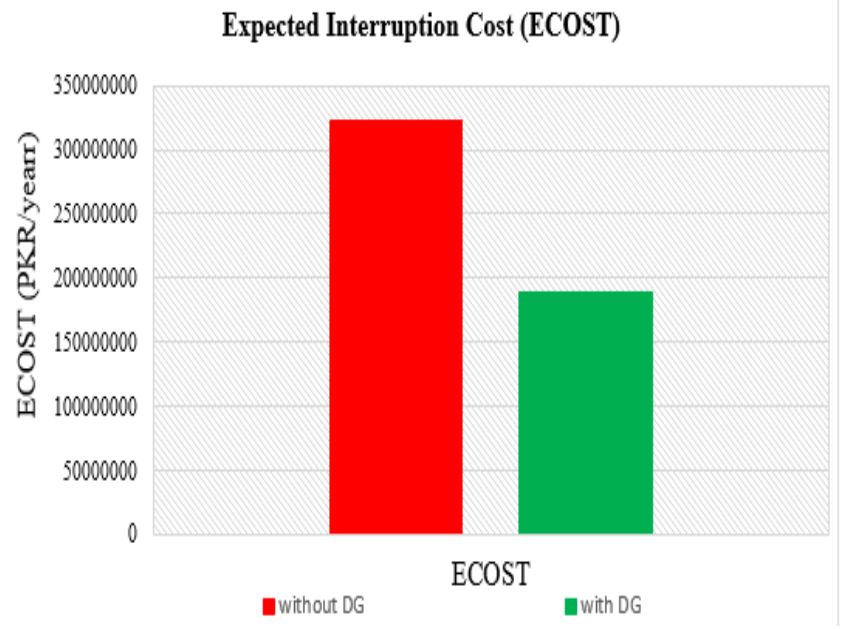

Figure 10: Comparison of interruption costs of two condition (with and without DG)

Table 4: Reliability assessment results of two condition

\begin{tabular}{|l|c|c|}
\hline \multicolumn{1}{|c|}{$\begin{array}{c}\text { Reliability } \\
\text { indices }\end{array}$} & $\begin{array}{c}\text { Without PV } \\
\text { Distributed } \\
\text { Generation }\end{array}$ & $\begin{array}{c}\text { With PV } \\
\text { Distributed } \\
\text { Generation }\end{array}$ \\
\hline SAIFI (f/year) & 61.1951 & 35.9855 \\
\hline SAIDI (hour/year) & 314.0 & 231.7216 \\
\hline CAIDI (hour) & 5.131 & 6.439 \\
\hline ASAI (p.u) & 0.9642 & 0.9735 \\
\hline ASUI (p.u) & 0.03585 & 0.02645 \\
\hline $\begin{array}{l}\text { EENS } \\
\text { (MWh/year) }\end{array}$ & 643.359 & 469.882 \\
\hline $\begin{array}{l}\text { AENS (MWh/ } \\
\text { customer/year) }\end{array}$ & 0.1859 & 0.1358 \\
\hline $\begin{array}{l}\text { ECOST } \\
\text { (PKR/year) }\end{array}$ & $322,210,390.15$ & $189,239,286.16$ \\
\hline IEAR (PKR/year) & 565.0 & 454.0 \\
\hline
\end{tabular}

\section{LEVELIZED COST OF ENERGY FOR PV DISTRIBUTED GENERATION}

The average cost of energy (LCOE) refers to the ratio of the cost of the power generation system (installation plus life cycle O\&M (operation and maintenance) costs) to the power generated by the energy generation system during its entire life cycle, in PKR/kilowatt-hour (kWh). The sum of the present value LCOE multiplied by the energy produced should equal the present value net cost. It must be noted that the total calculation starts from $t=0$ and includes project costs that are not discounted at the beginning of the first year and there are no system energies output to be degraded.

LCOE calculations are highly sensitive to system installation costs, operation and maintenance costs, system lifetime, local 
solar resources and climate, photovoltaic modules orientation, financing terms and conditions, taxes and state policies. Therefore, the photovoltaic levelized cost of energy (LCOE) estimates vary significantly based on the assumptions made when assigning the values to these variables [25, 26].

The general calculation method for levelized cost of energy (LCOE) are expressed by equations (19-21). The energy produced in the given year $\left(E_{t}\right)$ is the annual rated output energy $\left(S_{t}\right)$ multiplied by the degradation factor $(1-d)$ which will decrease the energy with time.

$$
\sum_{t=0}^{T}\left(\frac{\mathrm{LCOE}}{(1+\mathrm{r})^{\mathrm{t}}} \times \mathrm{E}_{\mathrm{t}}\right)=\sum_{t=0}^{T} \frac{\mathrm{C}_{\mathrm{t}}}{(1+\mathrm{r})^{\mathrm{t}}}
$$

$$
L C O E=\frac{\sum_{t=0}^{T} \frac{C_{t}}{(1+r)^{t}}}{\sum_{t=0}^{T} \frac{E_{t}}{(1+r)^{t}}}
$$

$$
L C O E=\frac{\sum_{t=0}^{T} \frac{\left(I_{t}+O_{t}+M_{t}+F_{t}\right)}{(1+r)^{t}}}{\sum_{t=0}^{T} \frac{S_{t}(1-d)^{t}}{(1+r)^{t}}}
$$

Where,

$\bullet \mathrm{t}=$ year $(\mathrm{t})$

- $\mathrm{T}=$ Life of project (years)

- $\mathrm{E}_{\mathrm{t}}=$ Energy produced for year $\mathrm{t}$

- $\mathrm{C}_{\mathrm{t}}=$ Net Cost of project for year $\mathrm{t}(€)$

- $\mathrm{I}_{\mathrm{t}}=$ Initial investment cost such as construction costs, installation costs

- $\mathrm{M}_{\mathrm{t}}=$ maintenance costs

- $\mathrm{O}_{\mathrm{t}}=$ Operation Costs for year $\mathrm{t}(€)$

- $\mathrm{F}_{\mathrm{t}}=$ Interest expenditure for year $\mathrm{t}(€)$

- $\mathrm{r}=$ Discount rate for year $\mathrm{t}(\%)$

- $\mathrm{S}_{\mathrm{t}}=$ Yearly rated energy output for year $\mathrm{t}$ (kWh/year)

$\bullet \mathrm{d}=$ Degradation rate $(\%)(0.20-0.50 \%)$
When the LCOE calculates, the financial parameters are required for the reference system design in shown Table 5.

Table 5: PV test system costs

\begin{tabular}{|l|c|}
\hline \multicolumn{1}{|c|}{ Installed Systems } & \multicolumn{1}{|c|}{$\begin{array}{c}\text { PV Distributed } \\
\text { Generation }\end{array}$} \\
\hline PV Installed Capacity & $500.04 \mathrm{~kW}$ \\
\hline Area & $44,032.9 \mathrm{ft}^{2}$ \\
\hline PV Module Efficiency & 19 \\
\hline PV Module Cost $\left(€ / \mathrm{kW}_{\mathrm{dc}}\right)$ & 0.28 \\
\hline $\begin{array}{l}\text { Installed Inverter Capacity } \\
(5 * 100 \mathrm{~kW})\end{array}$ & $500 \mathrm{~kW}$ \\
\hline Inverter Cost & $€ 500$ \\
\hline Discount Rate $(\%)$ & 7 \\
\hline Fixed Costs $(€)$ & 131520 \\
\hline System Degradation $(\% / \mathrm{year})$ & 0.5 \\
\hline Other O\&M Costs $(€ / \mathrm{kW}-\mathrm{yr})$ & 15 \\
\hline
\end{tabular}

As shown in Table 6, the installation costs have been reduced by $65.0 \%$, inverter replacement costs have been reduced by $58.0 \%$, operation and maintenance costs have been reduced by $41.0 \%$, annual degradation rate has been reduced by $25.0 \%$, and equity discount rate has been reduced by $23.0 \%$, the debt interest rate has been reduced by $13.0 \%$, and the debt ratio has increased by $17.0 \%$ from 2018 to 2025 . When evaluating the levelized cost of energy (LCOE) of photovoltaic distributed generation, LCOE reduces from $0.120 € / \mathrm{kWh}$ in 2018 to $0.106 € / \mathrm{kWh}$ in 2025 . This result is shown in Figure 11 and cost benefits and profits of PV DG for test system are shown in Table. 6.

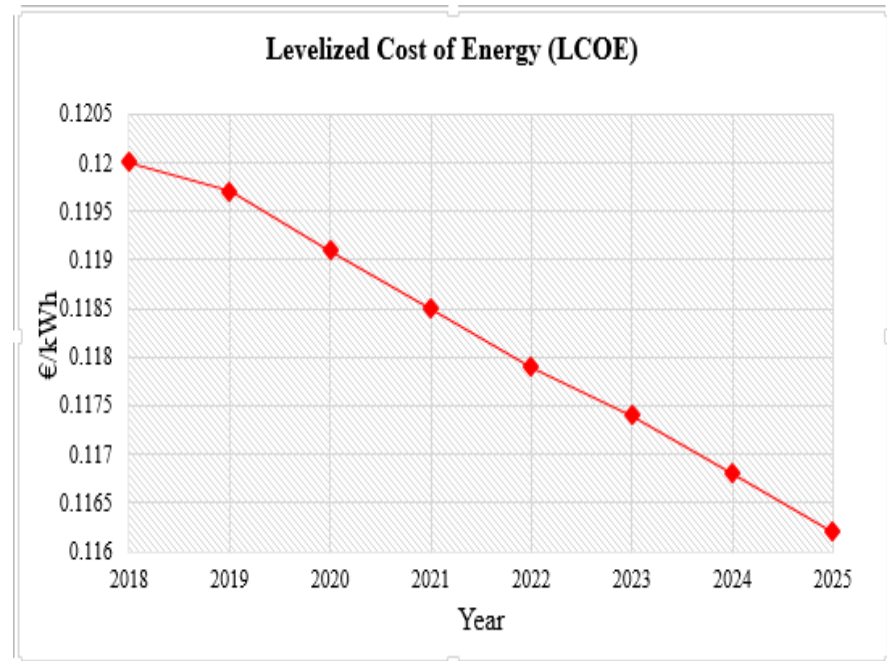

Figure 11: Levelized cost of energy for Integrating PV DG 
Table 6: Cost Benefits and Profit of DG for Test System

\begin{tabular}{|c|c|c|c|c|c|c|c|}
\hline & 2019 & 2020 & 2021 & 2022 & 2023 & 2024 & 2025 \\
\hline $\begin{array}{l}\text { Installed } \\
\text { Cost }\end{array}$ & $\begin{array}{c}€ 131, \\
520\end{array}$ & $\begin{array}{c}€ 117, \\
272\end{array}$ & $\begin{array}{c}€ 103, \\
024\end{array}$ & $\begin{array}{c}€ 88,7 \\
76\end{array}$ & $\begin{array}{c}€ 74,5 \\
28\end{array}$ & $\begin{array}{c}€ 60,2 \\
80\end{array}$ & $€ 46,03 \AA$ \\
\hline $\begin{array}{l}\text { Annual } \\
\text { Degradati } \\
\text { on }\end{array}$ & $\begin{array}{c}1.00 \\
\%\end{array}$ & $\begin{array}{c}0.95 \\
\%\end{array}$ & $\begin{array}{c}0.90 \\
\%\end{array}$ & $\begin{array}{c}0.85 \\
\%\end{array}$ & $\begin{array}{c}0.80 \\
\%\end{array}$ & $\begin{array}{c}0.75 \\
\%\end{array}$ & $75 \%$ \\
\hline $\begin{array}{l}\text { Inverter } \\
\text { Cost }\end{array}$ & $€ 500$ & $€ 450$ & $€ 402$ & $€ 354$ & $€ 306$ & $€ 258$ & $€ 210$ \\
\hline $\begin{array}{l}\mathrm{O} \& \mathrm{M} \\
\text { expenses }\end{array}$ & 15 & $\begin{array}{c}13.97 \\
5\end{array}$ & 12.95 & $\begin{array}{c}11.92 \\
5\end{array}$ & 10.9 & 9.875 & $\begin{array}{r}8.85 \\
4 .\end{array}$ \\
\hline
\end{tabular}

\section{CONCLUSION}

The purpose of this research describes the importance of sustainable energy development. In order to obtain reliable and sustainable energy, the test system needs a second power source like PV energy. According to reliability assessment of test system before integrating PV DG, average service availability index (ASAI) is $0.9642 \mathrm{pu}$ and the average service unavailability index (ASUI) is 0.03585. Then, expected energy not supplied (EENS) is $643.359 \mathrm{MWh} /$ year and average energy not supplied (AENS) is 0.1859 $\mathrm{MWh} /$ customer/year. Expected interruption cost (ECOST) is $322,210,390.15 \mathrm{PKR} /$ year and interrupted energy assessment rate (IEAR) is 565.0 PKR/year. According to reliability assessment of test system after integrating PV DG, average service availability index (ASAI) is $0.9735 \mathrm{pu}$ and the average service unavailability index (ASUI) is 0.02645 . Therefore, expected energy not supplied (EENS) is $469.882 \mathrm{MWh} / \mathrm{year}$ and average energy not supplied (AENS) is 0.1358 $\mathrm{MWh} /$ customer/year. Expected interruption cost (ECOST) is $189,239,286.16 \mathrm{PKR} /$ year and interrupted energy assessment rate (IEAR) is $464.0 \mathrm{PKR} /$ year. Therefore, based on expected energy not supplied (EENS), the system reliability is increased by 27.0 percent. In addition, this article describes the costs and benefits of DG in the $132 \mathrm{kV} / 11 \mathrm{kV}$ distribution grid station, Faisalabad by integrating photovoltaic DG. This article mainly introduces the reliability index results with and without DG and the average energy cost (LCOE) results from 2018 to 2025.

\section{REFERENCES}

1. International Energy Agency. World Energy Outlook 2018. Available online: https://www.iea.org/weo2018/ (accessed on 30 January 2021).

2. Minnaar, U. J. (2016). Regulatory practices and Distribution System Cost impact studies for distributed generation: Considerations for South African distribution utilities and regulators. Renewable and Sustainable Energy 10.1016/j.rser.2015.12.015. 1139-1149. doi: de Faria Jr, H., Trigoso, F. B. and Cavalcanti, J. A. (2017). Review of distributed generation with photovoltaic grid connected systems in Brazil: Challenges and prospects. Renewable and Sustainable Energy Reviews, 75, 469-475. doi: 10.1016/j.rser.2016.10.076.

4. Pingkuo, L. and Zhongfu, T. (2016). How to develop distributed generation in China: In the context of the reformation of electric power system. Renewable and Sustainable Energy Reviews, 66, 10-26. doi: 10.1016/j.rser.2016.07.055.

5. Eberhard, A. (2015). Feed-in Tariffs or Auctions? Procuring Renewable Energy Supply in South Africa; View point; no. 338; World Bank: Washington, DC, USA, 2015; Available online: http://www.gsb.uct.ac.za/files/

FeedintariffsorAuctions.pdf (accessed on 29 March 2021).

6. Microgrids: The Future of Energy. Published on Thursday, 8 May 2014. Available online: https://www.enel.com/en/media/news/d201405-microgr ids-the-future-of-energy.html (accessed on 01 April 2021).

7. Thornton, A. and Monroy, C. R. (2011). Distributed power generation in the United States. Renewable and Sustainable Energy Reviews, 15(9), 4809-4817. doi: 10.1016/j.rser.2011.07.070.

8. Raju, K., Madurai Elavarasan, R. and Mihet-Popa, L. (2020). An assessment of onshore and offshore wind energy potential in India using moth flame optimization. Energies, 13(12), $3063 . \quad$ doi: 10.3390/en13123063.

9. Elavarasan, R. M. (2019). The motivation for renewable energy and its comparison with other energy sources: A review. European Journal of Sustainable Development Research, 3(1), em0076. doi: 10.20897/ejosdr/4005.

10. Kumar, N. M., Chopra, S. S., Chand, A. A., Elavarasan, R. M. and Shafiullah, G. M. (2020). Hybrid renewable energy microgrid for a residential community: A techno-economic and environmental perspective in the context of the SDG7. Sustainability, 12(10), 3944. doi: 10.3390/su12103944. 
11. Elavarasan, R. M., Shafiullah, G. M., Padmanaban, S., Kumar, N. M., Annam, A., Vetrichelvan, A. M. and Holm-Nielsen, J. B. (2020). A comprehensive review on renewable energy development, challenges, and policies of leading Indian states with an international perspective. IEEE Access, 8, 74432-74457. doi: 10.1109/ACCESS.2020.2988011.

12. Elavarasan, R. M., Shafiullah, G. M., Manoj Kumar, N. and Padmanaban, S. (2020). A state-of-the-art review on the drive of renewables in Gujarat, state of India: present situation, barriers and future initiatives. Energies, 13(1), $40 . \quad$ doi: 10.3390/en 13010040.

13. Madurai Elavarasan, R., Selvamanohar, L., Raju, K., Vijayaraghavan, R. R., Subburaj, R., Nurunnabi, M. and Das, N. (2020). A holistic review of the present and future drivers of the renewable energy mix in Maharashtra, state of India. Sustainability, 12(16), 6596. doi: 10.3390/su12166596.

14. Tamoor, M., Tahir, M. A. B., \& Zaka, M. A. (2021). Energy Management System for Integration of Different Renewable Energy System into Microgrids. International Journal of Advanced Trends in Computer Science and Engineering, 10(2), 1234 1242. doi: 10.30534/ijatcse/2021/1061022021.

15. Tan, X., Li, Q. and Wang, H. (2013). Advances and trends of energy storage technology in microgrid. International Journal of Electrical Power \& Energy Systems, 44(1), 179-191. doi: 10.1016/j.ijepes.2012.07.015

16. Schoniger, F., Thonig, R., Resch, G. and Lilliestam, J. 2021. Making the sun shine at night: comparing the cost of dispatchable concentrating solar power and photovoltaics with storage. Energy Sources, Part B: Economics, Planning, and Policy, 16(1), 55-74. doi: 10.1080/15567249.2020.1843565.

17. Tamoor, M., Tahir, M. S., Sagir, M., Tahir, M. B., Iqbal, S., \& Nawaz, T. (2020). Design of 3 kW integrated power generation system from solar and biogas. International Journal of Hydrogen Energy, 45(23), 12711-12720. doi: 10.1016/j.ijhydene.2020.02.207

18. Phuangpornpitak, N., Prommee, W., Tia, S. and Phuangpornpitak, W. (2010). A study of particle swarm technique for renewable energy power systems. In Proceedings of the international conference on energy and sustainable development: issues and strategies (ESD 2010) (pp. 1-6). IEEE. doi: 10.1109/ESD.2010.5598791.
19. Fateh, H., Safari, A., Bahramara, S. (2020). A Bi-Level Optimization Approach for Optimal Operation of Distribution Networks with Retailers and Micro-grids. Journal of Operation and Automation in Power Engineering, 8(1), 15-21. doi: 10.22098/joape.2019.5432.1407

20. Yousefi, H., Gholamian, S., Zakariazadeh, A. (2020). Distributed Voltage Control in Distribution Networks with High Penetration of Photovoltaic Systems. Journal of Operation and Automation in Power Engineering, 8(2), 164-171. doi: 10.22098/joape.2020.6259.1472

21. Rao, J. M., Prasad, P. V. N. and Das, G. T. R. (2010). Customer outage cost evaluation in electric power systems. ARPN Journal of Engineering and Applied Sciences, 5(8), 88-96.

22. Chen, G., Zhang, F., You, D., Wang, Y., Lu, G., Zou, Q., $\& \mathrm{Xu}$, H. (2017). Reliability evaluation of distribution system with distributed generation. In IOP Conference Series: Materials Science and Engineering (Vol. 224, No. 1, p. 012035). IOP Publishing.

23. Faisalabad Electric Supply Company. 132/11kV Distribution Grid Station Faisalabad Documents of system data, load data and interruption data 2020-2021.

24. Billinton, R., \& Wang, P. (1998). Distribution system reliability cost/worth analysis using analytical and sequential simulation techniques. IEEE Transactions on Power Systems, 13(4), 1245-1250. DOI: $10.1109 / 59.736248$

25. Lai, C. S. and McCulloch, M. D. (2016). Levelized cost of energy for PV and grid scale energy storage systems. arXiv preprint arXiv:1609.06000.

26. Cameron, C. P. and Goodrich, A. C. (2010). The levelized cost of energy for distributed PV: A parametric study. In 2010 35th IEEE Photovoltaic Specialists Conference (pp. 000529-000534). IEEE. doi: 10.1109/PVSC.2010.5616811. 